\title{
Carbimazole and autoantibody synthesis in Hashimoto's thyroiditis
}

\author{
ALAN M MCGREGOR， H KAYE IBBERTSON，BERNARD REES SMITH， REGINALD HALL
}

\section{Summary and conclusions}

Serum thyroxine, thyrotrophin, and thyroid microsomal antibody levels were measured in 20 patients with Hashimoto's thyroiditis and hypothyroidism before, during, and after treatment with carbimazole or placebo. Thyroid microsomal antibody levels fell during treatment in the 10 patients who received carbimazole, while serum thyroxine and thyrotrophin levels did not change. There were no changes in the placebo group.

The study proves support for the concept that carbimazole may act directly on autoantibody synthesising lymphocytes localised in the thyroid. Such an effect might be valuable in influencing the autoimmune process in autoimmune thyroid disease.

\section{Introduction}

Several studies have indicated that thyroid autoantibody levels fall during antithyroid drug treatment of patients with Graves's disease. ${ }^{1-5}$ This phenomenon could reflect spontaneous changes in autoantibody levels or some direct or indirect effect of antithyroid drugs on the autoimmune process. Recent observations suggest, however, that antithyroid drugs may have a direct action on autoantibody synthesis ${ }^{6}$ and to investigate this possibility further we studied the influence of carbimazole on thyroid microsomal antibody levels in patients with Hashimoto's thyroiditis.

\section{Patients and methods}

Twenty patients with Hashimoto's thyroiditis and hypothyroidism (diagnosed on clinical, biochemical, and immunological grounds) were studied. The patients were taking thyroxine replacement therapy $(0.15 \mathrm{mg} /$ day $)$, which was continued throughout the investigations. An initial blood sample was taken and three weeks later the patients were divided into two similar groups, 10 being treated with carbimazole (15 mg three times daily) and 10 with placebo. Patients in the carbimazole-treated group had a mean ( $\$ SEM) age of $54 \quad 3$ years, and nine were women. All 10 of the placebo-treated group were women, and their mean age was $51+2$ years. Blood samples were taken every three weeks and analysed for serum thyroxine, ${ }^{7}$ serum thyrotrophin, ${ }^{8}$ and thyroid microsomal antibody. ${ }^{9}$ After 12 weeks treatment with carbimazole or placebo was stopped and a final blood sample taken three weeks later.

The statistical significance of the changes in thyroxine, thyrotrophin, and microsomal antibody levels was assessed using a paired $t$ test.

\footnotetext{
Department of Medicine, Welsh National School of Medicine, Cardiff CF4 4XN

ALAN M McGREGOR, MA, MRCP, lccturer

BERNARD REES SMITH, PHD, senior lecturer

REGINALD HALL, MD, FRCP, professor of medicine
}

\footnotetext{
Department of Medicine, University of Auckland, Auckland, New Zealand

H KAYE IBBERTSON, FRCP, FRACP, professor of endocrinology
}

\section{Results}

Serum microsomal antibody levels fell in nine of the 10 patients treated with carbimazole. The fall was statistically significant for the group after six weeks' drug administration and maximal after nine weeks (see figure). Thereafter the mean antibody levels rose slightly and this trend continued over the three weeks after withdrawal of carbimazole treatment. These increased values reflected increases in antibody titres in only three patients, however, the levels remaining unchanged in six and decreasing in one patient; overall the mean increases for the group were not statistically significant $(p>0 \cdot 1)$.

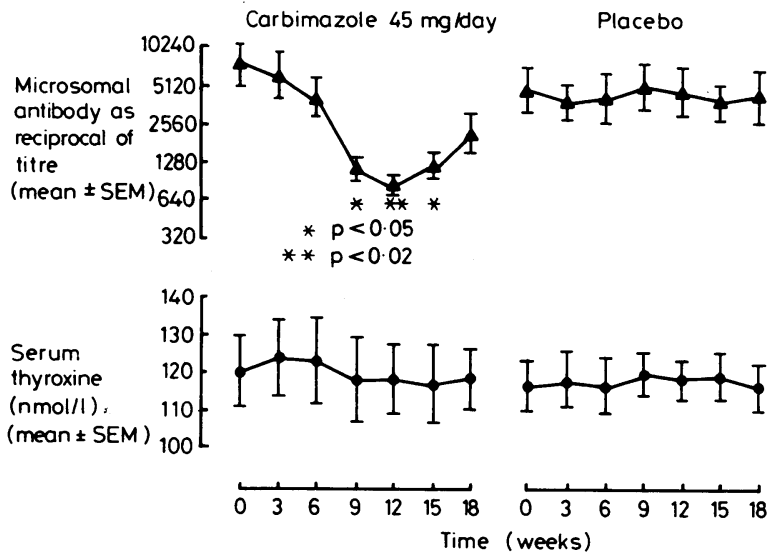

Influence of carbimazole and placebo treatment on microsomal antibody levels in Hashimoto's thyroiditis.

There was no significant change in serum thyroid hormone or thyrotrophin levels during antithyroid drug treatment (see figure), although two patients showed an approximately twofold increase in serum thyrotrophin levels after nine weeks' carbimazole.

Serum microsomal antibody, thyroxine, and thyrotrophin levels showed no changes in the placebo-treated group (see figure).

\section{Discussion}

Thyroid microsomal antibody levels fell in patients with Hashimoto's disease who were treated with carbimazole. This effect appeared to be independent of thyroxine or thyrotrophin levels as these values did not change during antithyroid drug administration. Our observations therefore support the suggestion $^{6}$ that carbimazole has a direct effect on the immune cells that synthesise thyroid autoantibodies. As the active metabolite of carbimazole (methimazole) is concentrated in the thyroid, ${ }^{1011}$ and lymphocytes localised in the thyroid seem to be a major site of thyroid autoantibody synthesis, ${ }^{12-14}$ the drug probably acts on these immune cells. Furthermore, recent studies in vitro have shown that methimazole, at concentrations similar to those which might be expected in the thyroid during treatment, strongly inhibits thyroid autoantibody synthesis by lymphocyte cultures from patients with Hashimoto's thyroiditis.

The effects of carbimazole on thyroid autoantibody levels in patients with Graves's disease ${ }^{1-6}$ are similar to those described here for Hashimoto's thyroiditis. Consequently in-vivo and invitro studies in both Hashimoto's and Graves's diseases suggest that carbimazole has a direct, inhibitory action on thyroid auto- 
antibody production. This effect could be of potential value in influencing the autoimmune process in these conditions.

This work was supported by grants from the Medical Research Council, the North of England Cancer Campaign, the Wellcome Trust, the League of Friends of the Royal Victoria Infirmary, the Ernest and Minnie Dawson Cancer Trust, the research committee, Newcastle Area Health Authority (Teaching), and the Welsh Office Scheme for Development of Health and Social Research. We are most grateful to Miss B Sims for secretarial help.

Correspondence to A M McG at above address.

\section{References}

${ }^{1}$ Pinchera A, Liberti P, Martino E, et al. Effects of antithyroid therapy on the LATS and the antithyroglobulin antibodies. $\mathcal{F}$ Clin Endocrinol Metab 1969;29:231-8.

2 Buchanan WW, Koutras DA, Crooks J, et al. The clinical significance of the complement fixation test in thyrotoxicosis. $\mathcal{F}$ Endocrinol $1962 ; 24$ : $115-25$.

${ }^{3}$ Mukhtar ED, Rees Smith B, Pyle G, Hall R, Vice P. Relation of thyroidstimulating immunoglobulins to thyroid function and effects of surgery, radioiodine and antithyroid drugs. Lancet 1975;ii :713-5.

${ }^{4}$ Fenzi G, Hashizume K, Roudebush CP, De Groot LJ. Changes in thyroidstimulating immunoglobulins during anti-thyroid therapy. $\mathcal{f}$ Clin Endocrinol Metab 1979;48:572-6.
5 McGregor AM, Petersen MM, Capiferri R, Evered DC, Rees Smith $B$, Hall $R$. Effects of radioiodine on thyrotrophin binding inhibiting immunoglobulins in Graves's disease. Clin Endocrinol 1979;11:437-44.

${ }^{6}$ McGregor AM, Petersen MM, McLachlan SM, Rooke P, Rees Smith B, Hall R. Carbimazole and the autoimmune response in Graves' disease. $N$ Engl f Med $1980 ; 303: 302-7$.

7 Evered DC, Vice PA, Green EC, Appleton DJ. Assessment of thyroid hormone assays. F Clin Pathol 1976;29:1054-9.

${ }^{8}$ Hall R. The immunoassay of TSH and its clinical applications. Clin Endocrinol 1972;1:115-9.

${ }^{9}$ Bird T, Stephenson J. Evaluation of a tanned red cell technique for thyroid microsomal antibodies. 7 Clin Pathol 1973;26:623-7.

10 Lazarus JH, Marchant B, Alexander WD, Clark DH. ${ }^{35}$ S-antithyroid drug concentration and organic binding of iodine in the human thyroid. Clin Endocrinol 1975;4:609-15.

11 Marchant B, Lees JFH, Alexander WD. Antithyroid drugs. Pharmacol Ther 1978;3:305-48.

12 Salabe GB, Davoli C, Andreoli M. Identification in the thyroid of antithyroglobulin antibodies in the fibrous variant of Hashimoto's thyroiditis. Int Arch Allergy 1974;47:63-79.

13 Totterman, T. Distribution of T-, B- and thyroglobulin-binding lymphocytes infiltrating the gland in Graves' disease, Hashimoto's thyroiditis and De Quervain's thyroiditis. Clin Immunol Immunopathol 1978;10: 270-7.

${ }^{14}$ McLachlan SM, McGregor AM, Rees Smith B, Hall R. Thyroid autoantibody synthesis by Hashimoto thyroid lymphocytes. Lancet $1979 ; \mathrm{i}$ : 162-3.

(Accepted 1 September 1980)

\title{
Thyroxine replacement therapy: prescribing patterns and problems in 2710 patients
}

\author{
SCOTTISH AUTOMATED FOLLOW-UP REGISTER GROUP
}

\section{Summary and conclusions}

The use of thyroxine replacement therapy was studied in 2710 patients with a previous diagnosis of either thyrotoxicosis or primary hypothyroidism. The patients, who were treated in five centres, were followed-up continuously using an automated register. Seventy per cent of patients had been prescribed daily doses of thyroxine of $200 \mu \mathrm{g}$ or more. The estimated 10-year cumulative incidence of detected undertreatment was $13.2 \%$ (95\% confidence limits $10 \cdot 9-15 \cdot 6 \%$ ). The median cumulative incidence of recognised overtreatment was $6 \cdot 2 \%$.

Improved patient education and the dissemination of guidelines to doctors on the use of thyroxine replacement may reduce the incidence of undertreatment or overtreatment.

\section{Introduction}

Overt spontaneous hypothyroidism is a relatively common condition with a prevalence of up to $2 \%$ of the general population aged 18 and over. ${ }^{1}$ To this must be added patients with congenital hypothyroidism, currently estimated at between 1 in 3000 to 1 in 9000 live births. ${ }^{2}$ Hypothyroidism is common in patients who have been treated for thyrotoxicosis; in a recent study in four different teaching hospital centres, the prevalence

Members of the Scottish Automated Follow-up Register Group (SAFUR) are: Dr P D Bewsher, Professor R D Weir, Aberdeen; Professor J Crooks, Mr A Gunn, Dr J N Macpherson, Dr T E Isles, Dundee; Dr D Dinwoodie, Professor J A Strong, Edinburgh; Dr W D Alexander, Dr R E Young, $\mathrm{G}$ Pearson, Mr I D Turner, Nottingham. of hypothyroidism ranged from $24 \%$ to $63 \%$ in a total of 1902 patients after radioiodine therapy and from $23 \%$ to $52 \%$ in 1428 patients after subtotal thyroidectomy (unpublished observations).

Many studies ${ }^{3}{ }^{4}$ have shown that patients often do not take long-term medication in the recommended dosage and sometimes stop taking it altogether either on their own initiative or because of the intervention of another doctor. The prevalence of inadequate treatment with thyroxine was as high as $75 \%$ in one study. ${ }^{5}$ This problem was re-examined in thyroxine-treated patients who were under continuous surveillance through a follow-up register ${ }^{6}$ and were offered an assessment of their thyroid status every 12 to 18 months over 10 years.

The Scottish Automated Follow-up Register (SAFUR) has been providing follow-up facilities for patients treated for thyroid disease since 1967, as a joint venture between hospital and primary care. The system is used by hospital doctors in five Scottish centres and 1547 general practitioners to follow-up patients treated by radioiodine, subtotal thyroidectomy, and thyroxine replacement. There are now over 6000 patients on the register. Follow-up examinations are usually carried out by general practitioners, and biochemical analyses, processing, and reporting of results are performed by a central registry with laboratory and computing facilities.

\section{Patients and methods}

Analysis of 2710 computer-held patient follow-up records produced information about 2926 prescriptions for thyroxine. Twenty-seven prescriptions $(0.9 \%)$ were for less than $100 \mu \mathrm{g} /$ day and $204(7 \%)$ for $300-500 \mu \mathrm{g} /$ day. Lists of these patients were sent to the centres concerned for checking for possible errors in recording and for appropriate action. In the remaining group of prescriptions only $861(29 \%)$ were for doses in the range of 100 to $150 \mu \mathrm{g}, 1714(59 \%)$ were for $200 \mu \mathrm{g}$, and $120(4 \%)$ for $250 \mu \mathrm{g}$.

When undertreatment was detected at the follow-up examinations? 